\title{
Internship programmes in the pharmacy faculties and their compliance with the standards: A study in
} Turkey

\author{
Gulbin Ozcelikay, Sidika Zübarioğlu \\ Faculty of Pharmacy, Ankara University, Ankara, Turkey
}

\author{
Keywords \\ Internship instruction \\ Pharmacy practice \\ Pharmacy programme
}

\author{
Correspondence \\ Gulbin Ozcelikay \\ Faculty of Pharmacy \\ Ankara University \\ Emniyet Mah. Degol Cd. \\ No: 4 Posta No:06560 \\ Yenimahalle, \\ Ankara \\ Turkey \\ gozcelikay@ankara.edu.tr
}

\begin{abstract}
Objective: Pharmacy faculties endeavour to equip future pharmacy candidates with upto-date drug knowledge and skills to prepare them for future professional life. To train pharmacists to play an active role in each field of pharmaceuticals according to a wide range of the pharmaceutical industry, is a challenging process that needs to be wellplanned. The internship programme is one of the building blocks of this challenging process. Methods: The document analysis method was used to conduct this research. The material of the study consists of the internship guidelines of a total of 48 programmes. Results: $79.5 \%$ of pharmacy faculties comply with standards in terms of internship periods and their durations. Another important point is internship areas and Turkey provides many options for these internships. Although $97.5 \%$ of the 39 pharmacy faculties (with a total of 43 pharmacy programmes) were up to date, $20.5 \%$ did not comply with the standards prepared by the Council of Higher Education in line with the European Union's directive no. 2005/36/EC. Discussion: It is not possible to discuss homogeneity between Turkey and the Turkish Republic of Northern Cyprus in terms of pharmacy programmes' internship practices as there exist significant differences between them. However, when Turkey is considered alone, $85.7 \%$ of faculties carried out internship practices with minor changes by adhering to the standards.
\end{abstract}

\section{Introduction}

The success of any profession lies in its contribution to society. Education is considered a key element in any profession; it defines existing values and norms about how the learned skills should be practised (Vestergaard et al., 2017). Pharmacy education in Turkey, as well as all over the world, includes theoretical and practical training courses besides internship programmes, and the duration of institutional education is five years. Pharmacy faculties endeavour to equip future pharmacy candidates with upto-date drug knowledge and skills to prepare them for professional life. To train pharmacists who play an active role in each field of pharmaceuticals according to a wide range of the pharmaceutical industry is a challenging process that needs to be well-planned. In the laboratory courses of pharmacy education, the student gets an opportunity to see, consolidate and evaluate what he/she has learned in the theoretical lessons. This educational process which is carried out in the faculty alone is, however, not enough to acquire pharmacy competencies. Supporting faculty education with internships and providing an opportunity to observe the professional life closely allows the student to measure his/her competencies to decide the field in which he/she can specialise. 
The journey of becoming a professional in the field of pharmacy builds its roots in strong foundational experiences in the early years of one's professional career. Students can have these experiences through internships in the community, hospital, and other settings in which pharmacists play a role. When a student engages in internships either before or during pharmacy school, it helps build an internal compass that will navigate the student in a direction that best fits their interests, personality, and goals. Truly, the best way to learn about a profession is to immerse oneself in it through hands-on work and training to get a better feel of what qualities are needed to work as a pharmacist in each setting (Reyes, 2017). There are certain skills that many pharmacy interns should have to carry out their responsibilities. Pharmacy internships are meant to expose students and graduates to pharmaceutical operations. The work can take place in either a healthcare facility or a pharmaceutical company (EU Monitor, 2005).

An internship is supposed to contribute to students' transition between theoretical knowledge and work, introducing students to professional practice. Hence, the outcome of an internship is much more than learning the skills demanded. It is also clear that pharmacy education programmes have to adapt to the changing role of pharmacists. In general, the curricula of pharmacy education in Europe are aligned with the European Union legislation EC 2005/36, which specifies demands on the education, including a six-month internship (Wallman, 2010).

The legal grounding of the internship in pharmacy education programme in Turkey, prepared by the Council of Higher Education in line with the European Union's directive no 2005/36/EC and 'Regulation on Determining the Minimum Education Conditions for Doctor, Nursing, Midwifery, Dentistry, Veterinary Medicine, Pharmacy and Architecture Education Programs', was enacted on 25 May 2018. Moreover, the standards for the internship programmes were written into the Core Pharmacy Education Programme document, which was prepared by the Turkey Faculty of Pharmacy Deans Council and it considered the education standards set by the Pharmacy Training Program Evaluation and the Accreditation Association. The set of regulations developed, which entered into force in Turkey with the European Union directive, allowed only community and hospital pharmacies to provide internship opportunities. In Turkey, the number of community pharmacies are limited by the population density; new regulations allows for one community pharmacy for every 3,500 people. The estimated population of Turkey in 2023 will be $84,247,088$ and therefore the allowed number of community pharmacies following this regulation, will be 24,070 . As of 2021, however, the number of community pharmacies in Turkey is 27,419 . Although it was not suggested by European directives, to increase employment opportunities for pharmacy graduates in Turkey, an article in 2018 was established to allow internships on the pharmaceutical industries.

This study aims to evaluate the compliance of the internship programmes of all pharmacy courses in Turkey according to the standards that are stated in the National Core Pharmacy Education Programme which was published in 2019. Additionally, by looking at all pharmacy programmes' internship instruction together, the authors will advise taking some precautions.

\section{Methods}

In this study a document analysis method, which is a qualitative data collection technique, was used. Internal standards and regulations of internship programmes from pharmacy faculties in Turkey and faculties which accept Turkish citizen students in the Turkish Republic of Northern Cyprus (TRNC) are taken into evaluation. The material of the study consists of the internship guidelines of a total of 48 programmes. Internship instructions were taken from the web pages of the Faculties, then the instructions were confirmed by contacting the Dean's Offices. The instructions were evaluated in terms of up-todateness, internship period, duration of periods and internship areas.

\section{Results}

In the 2020-2021 academic year, 39 pharmacy faculties admitted students in Turkey, and four pharmacy faculties accepted Turkish citizen students in TRNC. In Turkey, 27 of the total pharmacy faculties belong to State universities while 12 belong to private foundations universities. The education language in State universities in Turkish, however, İstanbul and Ankara Universities have a pharmacy programme in the English language as well as the Turkish pharmacy programme. Among the 12 private foundation universities, nine of them had Turkish as the main education language, three of them (Acıbadem, Altınbaş and Yeditepe Universities) had English as the main education language, and three universities (İstinye and Medipol (Istanbul and Ankara)) have pharmacy programmes in the English and Turkish language 


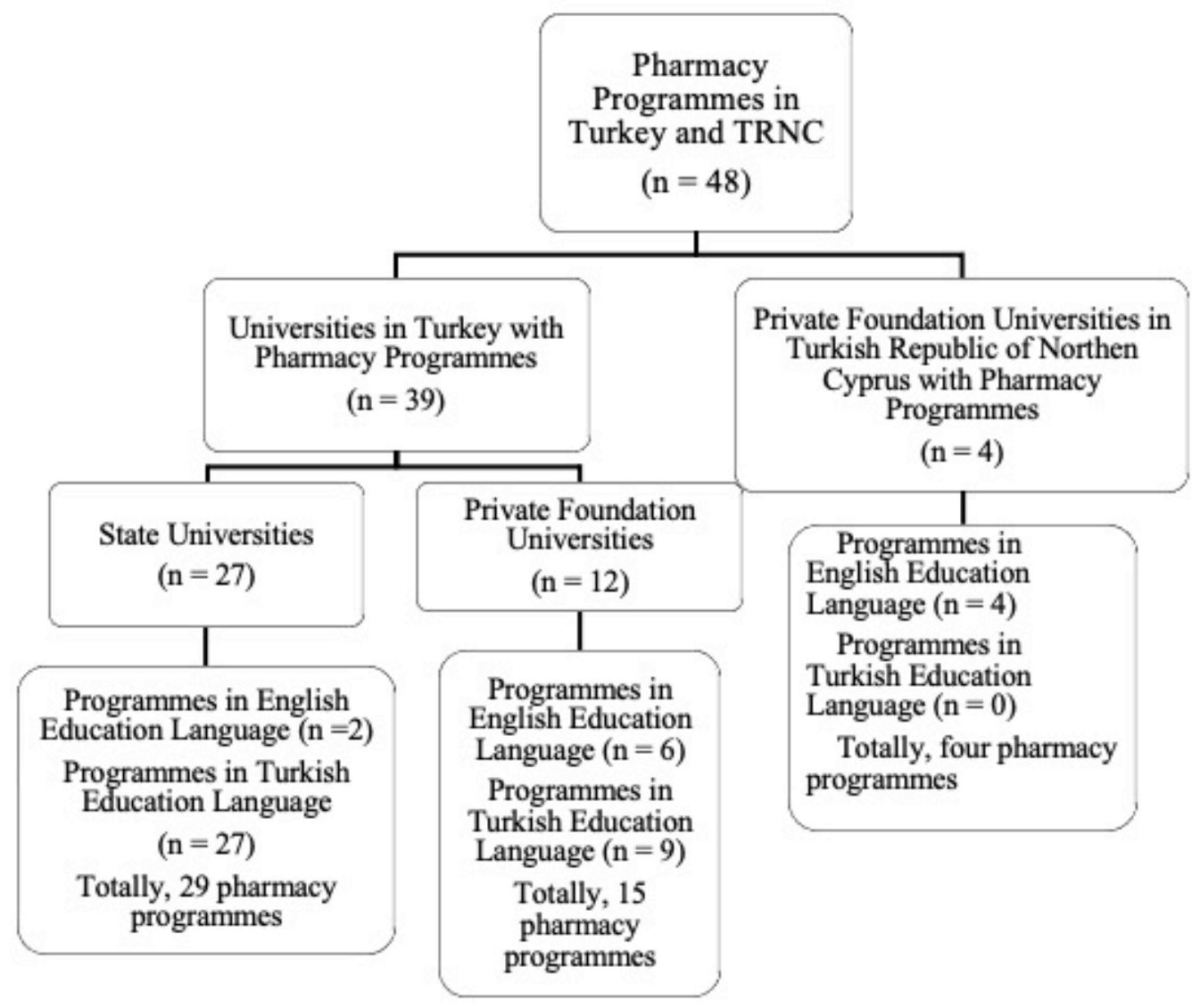

Figure 1: Pharmacy programmes in Turkey and TRCN (Eczacilık Programı Bulunan Tüm Üniversiteler, n.d.)

pharmacy programme. All of the pharmacy programmes evaluated from TRNC belong to private foundation universities, and the education language is English. At the time of writing, the total number of pharmacy programmes in Turkey is 48 (Figure 1). In each faculty of pharmacy, there is an internship commission to organise the internship programmes.

The internship core training programme standards are determined by the Deans Council of the Pharmacy Faculties, and are given in Table I. Internship practices in faculties have been evaluated within the framework of these standards. According to Table I, internships have to be done in four periods and at least for six months in community pharmacy, hospital pharmacy and pharmaceutical industry. The internship programme of each term is prepared by the faculty and fourth term internships are supervised. Internship attendance is mandatory. The student prepares a report at the end of each internship period and sits the internship exam.

The internship programme competencies are instructed according to the fields and graded from 1 to 4 (Table II); In Table III, 40 competencies which are in the level of 3 and 4 are shown together with the internship field they would
Table I: Recommended internship terms and durations by deans council of the pharmacy faculties

\begin{tabular}{|c|c|c|c|c|}
\hline & $\begin{array}{l}\text { Term of the } \\
\text { internship }\end{array}$ & $\begin{array}{l}\text { Internship } \\
\text { duration } \\
\text { Workday }\end{array}$ & Month & $\begin{array}{l}\text { Areas that } \\
\text { Internship can } \\
\text { be completed }\end{array}$ \\
\hline $\begin{array}{l}\text { Internship } \\
\text { I }\end{array}$ & $\begin{array}{l}\text { Summer Intern- } \\
\text { ship (At the end } \\
\text { of the fourth } \\
\text { term) }\end{array}$ & 20 & 1 & $\begin{array}{l}\text { Community/ } \\
\text { Hospital } \\
\text { Pharmacy }\end{array}$ \\
\hline $\begin{array}{l}\text { Internship } \\
\text { II }\end{array}$ & $\begin{array}{l}\text { Summer Intern- } \\
\text { ship (At the end } \\
\text { of the sixth } \\
\text { term) }\end{array}$ & $20-30$ & $1-1.5$ & $\begin{array}{l}\text { Community/ } \\
\text { Hospital } \\
\text { Pharmacy }\end{array}$ \\
\hline $\begin{array}{l}\text { Internship } \\
\text { III }\end{array}$ & $\begin{array}{l}\text { Summer Intern- } \\
\text { ship (At the end } \\
\text { of the eighth } \\
\text { term) }\end{array}$ & $20-30$ & $1-1.5$ & $\begin{array}{l}\text { Community/ } \\
\text { Hospital } \\
\text { Pharmacy and } \\
\text { Drug Industry }\end{array}$ \\
\hline $\begin{array}{l}\text { Internship } \\
\text { IV }\end{array}$ & $\begin{array}{l}\text { Term Internship } \\
\text { (At the ninth } \\
\text { and/or tenth } \\
\text { term) }\end{array}$ & $40-60$ & $2-3$ & $\begin{array}{l}\text { Community/ } \\
\text { Hospital } \\
\text { Pharmacy and } \\
\text { Drug Industry }\end{array}$ \\
\hline $\begin{array}{l}\text { Total } \\
\text { Internship } \\
\text { Duration }\end{array}$ & & 120 & 6 & \\
\hline
\end{tabular}


Table II: Definition of pharmacy practice learning levels within the scope of internship competencies (Özçelikay, 2019)

\begin{tabular}{ll}
\hline Level & Definition of the level \\
\hline 1 & $\begin{array}{l}\text { Has information about how the application is done } \\
\text { and provides guidance. }\end{array}$ \\
2 & $\begin{array}{l}\text { Makes the application with source/ guide/ instruction } \\
\text { or with help. }\end{array}$ \\
3 & $\begin{array}{l}\text { Does general applications without help. } \\
\text { Manages complex situations alone. }\end{array}$
\end{tabular}

be acquired. It has not been evaluated in this study whether the competence of the internship has been reached by the internship programme.

Internship instruction of pharmacy faculties was examined in-detail and evaluated in terms of compliance with the standards and categorised in Table IV. Programmes that have an application different from the column headings that are given in Table IV are also specified in parentheses. As well as throughout the world also in Turkey internship durations are determined monthly, however considering the official holidays, internship durations are also handled on a work-day basis. To comply with the standards the internship duration must be at least six months; Programmes that do not comply with the standards with contrary situations are given in Table $\mathrm{V}$. The programmes that meet the minimum conditions of the standards have been accepted under the standards and defined as 'Suitable' in Table IV while unsuitable programmes are defined as 'Antithetical'.

To determine the up-to-dateness of internship guidelines/ practices, 'The decision to add' industrial internships 'to the Faculty of Pharmacy internships' has been implemented following the publication of the Official Gazette on the 25 May 2018 and is the latest change in pharmacy internship programmes (Health Services Pricing Commission, 2018). Therefore, all programmes updated in 2018 and afterwards, are considered up-to-date. In this aspect, the pharmacy programme of Hacettepe University is the only pharmacy programme in Turkey that is not up to date since it was updated before 2018. What is most important for pharmacy programmes, however, is integrating innovations into their internship systems.

The duration and location of the internships are given in Table VI. Afyonkarahisar, Başkent, istanbul Health and Technology, Ankara Medipol universities were not included by the authors since their pharmacy programmes are relatively new new and their internship guidelines are not yet published. East Mediterranean university has not been compared with other programmes since it follows a completely autonomous internship programme and the internship practices vary according to which of the five or six year pharmacy programmes the students are enrolled in. Additionally, universities with two pharmacy programmes (one in Turkish and on in English) were considered as a single programme in this study because their internship practices are the same.

It has been observed that all programmes provide internship opportunities in all fields specified in the standards, however, it is noteworthy that these opportunities differ according to the internship periods. In general, while community and hospital pharmacy internships are intensive in Internship I and Internship II periods, the student is also entitled to pharmaceutical industry internships in future internships. An issue which must be addressed is that only six universities (Ağrı İbrahim Çeçen, Atatürk, Erzincan Binali Yıldırım, İstinye, Lokman Hekim, Girne American University) added clinical pharmacy internships to their internship practices.

Among 48 active pharmacy programmes in Turkey: four faculties with a total of five pharmacy programmes (Afyonkarahisar, Başkent, Ankara Medipol (two pharmacy programmes in Turkish and English), İstanbul Health and Technology universities) could not be evaluated since their internship guidelines were not published. Ankara, i̇stanbul, Istinye, and İstanbul Medipol universities have English pharmacy programmes besides Turkish ones, however, because there is no difference between these programmes in the factors examined for the study, these programmes are considered as a single programme based on the university. Considering these situations, 39 universities could be evaluated in Table I, and 31 universities among them (79.5\%) are evaluated as following the standards while 8 universities $(20.5 \%)$ are evaluated as not conforming to standards as shown in Figure 2.

Although $97.5 \%$ of 39 pharmacy faculties (out of 43 pharmacy programmes) were historically up to date, 20.5\% did not comply with the standards which shows that the internship guidelines had not been updated by the faculties and have also not been updated functionally.

The areas where the internships take place are at least as important as the internship periods and durations. When the pharmacy programmes are examined in this respect; It is seen that the programmes provide opportunities for students in all areas of community pharmacy, hospital pharmacy and pharmaceutical industry, but these opportunities differ according to the internship periods.

The pharmacy internships are a significant part of undergraduate pharmacy education worldwide. Most commonly, the internship is scheduled in the six month to 
Table III: Competences and their levels that gained during internships according to internship area (Özçelikay, 2019)

Competence
Provides consultancy on traditional herbal medicinal products.
Prepares medicinal teas and provide consultancy on medicinal teas.
Takes the patient's medication history.
Consulting in the rational and safe use of food supplements.
Runs and manages the pharmacy store.
Uses effective communication knowledge and skills.
Uses his / her knowledge about the historical development of the pharmacy profession
when necessary.
Evaluates frequently encountered symptoms and provides necessary guidance.
Provides healthy life consultancy within the framework of their professional competencies.

Uses information management systems in pharmacy. $\quad 4$

Prepares the magistral preparation.

Informs the patient and the relevant healthcare personnel about the rational and safe drug 3 use in chronic diseases.

Informs patients and relevant healthcare personnel about rational and safe drug use in 3 special patient groups.

Informs the patient about the rational and safe use of medical devices used in chronic 4 diseases.

Identifies and evaluates drug-drug / food / natural product / disease interactions.

Controls the doses of medications.

\section{Level Area of internship that competence gained}

3

3

3

3

3

Community Pharmacy

Hospital Pharmacy

4

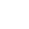

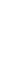

(1)

Applies rational drug use principles.

Creates a patient profile and monitors the drug treatment process. $\quad 4$

During the treatment, monitors and evaluate patient compliance. 3

Provides pharmaceutical care / clinical pharmacy service. 3

Makes pharmacy practices based on scientific evidence. 4

Prepares prescription and non-prescription drugs, presents them to the patient and record. $\quad 4$

Presents and administers special prescription drugs 4

Uses thin layer chromatography method in drug analysis. 3

Prepares traditional herbal medicinal products. 3

Develops drug formulation. 3

Does pre-formulation study. 3

Performs raw material / semi-finished / finished product quality control for pharmaceutical / 3 medical device / cosmetic products.

\begin{tabular}{lll}
\hline Prepares medicine under antiseptic conditions. & 4 & Hospital Pharmacy/ Drug Industry \\
\hline Evaluates the metabolism of active pharmaceutical ingredient. & 3 & 4 \\
Makes pharmaceutical calculations. & 3 & 3 \\
Provides decontamination, disinfection, sterilization, antisepsis conditions. & 4 & Community Pharmacy/ Hospital Pharmacy/ Drug Industry \\
Identifies and evaluates the side / adverse effects of drugs. & 3 \\
Participates in pharmacovigilance practice. & 3 \\
Contributes to cost minimization in pharmaceutical expenditures by providing & 4 \\
bioequivalence where appropriate. & 4 \\
Evaluates the regulations, laws and policies related to health and medicine. & 4 \\
Manages the storage, stocking, distribution and disposal processes of pharmaceutical / \\
medical device / cosmetic / herbal medical products. \\
Applies ethical principles and rules. \\
Uses leadership principles in professional practice. & 4
\end{tabular}


Table IV: Internship terms and durations, total internship duration and up-to-dateness of the pharmacy programmes by universities

\begin{tabular}{|c|c|c|c|c|c|c|c|c|}
\hline Name of the University & $\begin{array}{l}\text { Internship I } \\
\text { At the end of } \\
\text { the 4th term } \\
\text { (workday) }\end{array}$ & $\begin{array}{l}\text { Internship II } \\
\text { At the end of } \\
\text { the 6th term } \\
\text { (workday) }\end{array}$ & $\begin{array}{l}\text { Internship III } \\
\text { At the end of the } \\
\text { 8th term } \\
\text { (workday) }\end{array}$ & $\begin{array}{l}\text { Internship IV } \\
\text { At the tenth } \\
\text { term (workday) }\end{array}$ & $\begin{array}{l}\text { Internship V } \\
\text { At the ninth } \\
\text { term } \\
\text { (workday) }\end{array}$ & $\begin{array}{l}\text { Total } \\
\text { Internship } \\
\text { Duration } \\
\text { (workday) }\end{array}$ & $\begin{array}{l}\text { Up-to- } \\
\text { dateness }\end{array}$ & $\begin{array}{l}\text { Compliance } \\
\text { with } \\
\text { standards }\end{array}$ \\
\hline 2.Afyonkarahisar & - & - & - & - & - & - & - & - \\
\hline $\begin{array}{l}\text { 3.Ağrı İbrahim Çeçen University } \\
\text { (n.d.) }\end{array}$ & 20 & 30 & 30 & 60 & - & 140 & 2018 & Suitable \\
\hline $\begin{array}{l}\text { 4.Anadolu University Pharmacy } \\
\text { Faculty (2019) }\end{array}$ & 20 & 30 & 30 & 40 & - & 120 & 2019 & Suitable \\
\hline $\begin{array}{l}\text { 5.Ankara University Faculty of } \\
\text { Pharmacy (2020) }\end{array}$ & 20 & 30 & 30 & 40 & - & 120 & 2020 & Suitable \\
\hline $\begin{array}{l}\text { 6.Atatürk University Faculty of } \\
\text { Pharmacy (n.d.) }\end{array}$ & 20 & 30 & 30 & 40 & - & 120 & 2018 & Suitable \\
\hline $\begin{array}{l}\text { 7.Çukurova University Faculty of } \\
\text { Pharmacy (n.d.) }\end{array}$ & 20 & 30 & 30 & 40 (At ninth and $t$ & tenth term) & 120 & 2020 & Suitable \\
\hline $\begin{array}{l}\text { 8.Dicle University Faculty of } \\
\text { Pharmacy (2021) }\end{array}$ & 10 & 20 & 30 & 60 & - & 120 & 2018 & Antithetical \\
\hline $\begin{array}{l}\text { 9.Ege University Faculty of } \\
\text { Pharmacy (2019) }\end{array}$ & 20 & 20 & 20 & 60 (At ninth and/c & or tenth term) & 120 & 2019 & Suitable \\
\hline $\begin{array}{l}\text { 10.Erciyes University Faculty of } \\
\text { Pharmacy (n.d.) }\end{array}$ & 25 & 28 & 25 & 28 & 28 & 132 & 2018 & Suitable \\
\hline $\begin{array}{l}\text { 11.Erzincan B. Yıldırım University } \\
\text { Faculty of Pharmacy (2018) }\end{array}$ & 20 & 30 & 20 & 60 & 10 & 140 & 2018 & Suitable \\
\hline $\begin{array}{l}\text { 12.Gazi University Faculty of } \\
\text { Pharmacy (n.d.) }\end{array}$ & 20 & 20 & 20 & 70 & - & 130 & 2018 & Suitable \\
\hline $\begin{array}{l}\text { 13. Hacettepe University Faculty } \\
\text { of Pharmacy (2015) }\end{array}$ & $\begin{array}{l}5 \text { (At third or } \\
\text { fourth term) }\end{array}$ & 30 & $\begin{array}{l}\text { 20(At seventh or } \\
\text { eighth term) }\end{array}$ & $\begin{array}{l}30 \text { (At the end of } \\
\text { the eighth term) }\end{array}$ & $\begin{array}{l}75 \text { (At tenth } \\
\text { term) }\end{array}$ & 160 & 2015 & Antithetical \\
\hline $\begin{array}{l}\text { 14.İnönü University Faculty of } \\
\text { Pharmacy (2017) }\end{array}$ & 25 & 25 & 20 & 70 (At ninth and/c & or tenth term) & 140 & 2018 & Suitable \\
\hline $\begin{array}{l}\text { 15.İstanbul University Faculty of } \\
\text { Pharmacy (n.d.) }\end{array}$ & 20 & $20-30$ & $20-30$ & 40 & 20 & $120-140$ & 2020 & Suitable \\
\hline $\begin{array}{l}\text { 17.Karadeniz Teknik University } \\
\text { Faculty of Pharmacy (n.d.) }\end{array}$ & 20 & 30 & 30 & 28 & 21 & 129 & 2019 & Suitable \\
\hline $\begin{array}{l}\text { 18.Marmara University Faculty of } \\
\text { Pharmacy (2018) }\end{array}$ & 20 & 30 & 25 & 55 & - & 130 & 2018 & Suitable \\
\hline $\begin{array}{l}\text { 19.Mersin University Faculty of } \\
\text { Pharmacy (2018) }\end{array}$ & 20 & 20 & 20 & 60 & - & 120 & 2018 & Suitable \\
\hline $\begin{array}{l}\text { 20. Sağlık Bilimleri University } \\
\text { Faculty of Pharmacy (2019) } \\
\text { (Hamidiye) }\end{array}$ & 20 & 30 & 30 & 40 & - & 120 & 2019 & Suitable \\
\hline $\begin{array}{l}\text { 21. Sağlık Bilimleri University } \\
\text { Faculty of Pharmacy (2019) } \\
\text { (Gülhane) }\end{array}$ & 22 & 44 & 22 & 44 & - & 132 & 2019 & Suitable \\
\hline $\begin{array}{l}\text { 22.Selçuk University Faculty of } \\
\text { Pharmacy (n.d.) }\end{array}$ & 20 & $20-30$ & $20-30$ & $40-60$ & - & $120-140$ & 2019 & Suitable \\
\hline $\begin{array}{l}\text { 23.Sivas Cumhuriyet University } \\
\text { Faculty of Pharmacy (n.d.) }\end{array}$ & 30 & 25 & 25 & 20 & 20 & 120 & 2019 & Suitable \\
\hline $\begin{array}{l}\text { 24. Süleyman Demirel University } \\
\text { Faculty of Pharmacy (2020) }\end{array}$ & 20 & 30 & 30 & 60 (At ninth and/c & or tenth term) & $120-140$ & 2020 & Suitable \\
\hline $\begin{array}{l}\text { 25.Trakya University Faculty of } \\
\text { Pharmacy (n.d.) }\end{array}$ & 20 & 20 & 30 & 50 & - & 120 & 2018 & Suitable \\
\hline $\begin{array}{l}\text { 26.Van Yüzüncü Yıl University } \\
\text { Faculty of Pharmacy (2019) }\end{array}$ & 26 & 26 & 27 & 28 & 28 & 135 & 2019 & Suitable \\
\hline $\begin{array}{l}\text { 27.Zonguldak Bülent } \\
\text { Ecevit University Faculty of } \\
\text { Pharmacy (2018) }\end{array}$ & - & 44 & 44 & 44 & - & 132 & 2018 & Antithetical \\
\hline 28.Acıbadem Mehmet & 20 & 30 & 30 & 60 & 30(elective) & $150(180)$ & 2018 & Suitable \\
\hline
\end{tabular}

Ali Aydınlar University Faculty of

Pharmacy (2018) 
Table IV: Internship terms and durations, total internship duration and up-to-dateness of the pharmacy programmes by universities (continued)

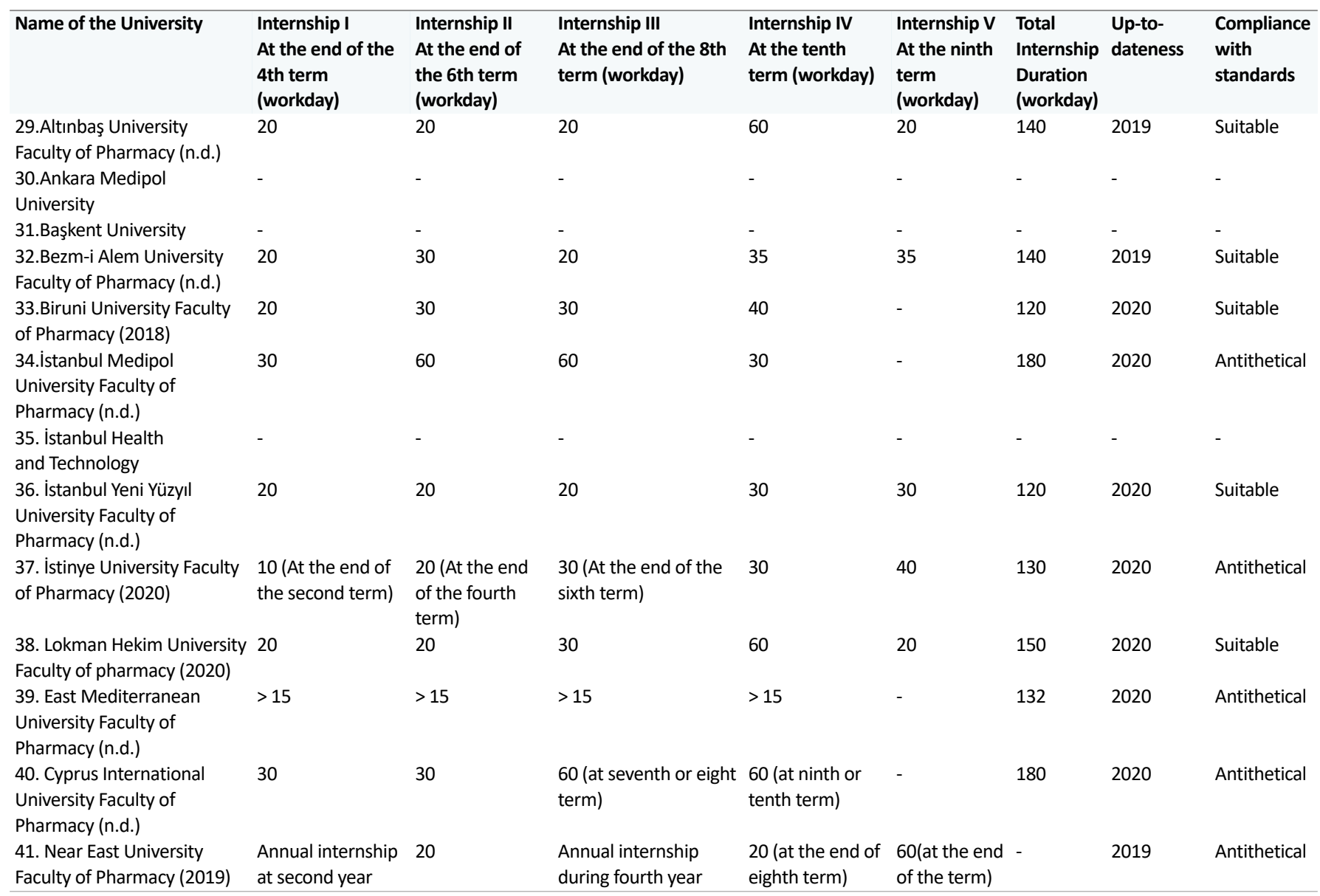

Table V: Universities that are considered as antithetical to standards and reasons of not meeting standards

\begin{tabular}{|c|c|}
\hline Name of the University & The reason for not meeting the standards \\
\hline 1.Dicle & Internship I (ten work-days); it is below the minimum period of 20 workdays for internship I. \\
\hline 2.Hacettepe & $\begin{array}{l}\text { Internship I is done in the third or fourth term as five work-days while internship I should be done as summer internship at the end of } \\
\text { the fourth term for at least } 20 \text { working days. }\end{array}$ \\
\hline 3.Zonguldak Bülent Ecevit & Internship programme consists of three terms; does not provide at least four internship terms. \\
\hline 4.İstanbul Medipol & Internship IV ( 30 work-days); it is below the minimum limit of Internship IV of 40 workdays. \\
\hline 5.İstinye & Internship programme does not include Internship III which should be required at the end of the $8^{\text {th }}$ term for at least 20 workdays. \\
\hline 6.East Mediterranean & Since the internship periods are at least 15 days of internship, they are below the minimum duration of internship terms. \\
\hline 7.Cyprus International & Internship III is done in the seventh or eighth term while it should be done at summer at the end of the eighth term. \\
\hline
\end{tabular}


Table VI: The areas where internship can be done according to the internship period




Table VI: The areas where internship can be done according to the internship period (continued)

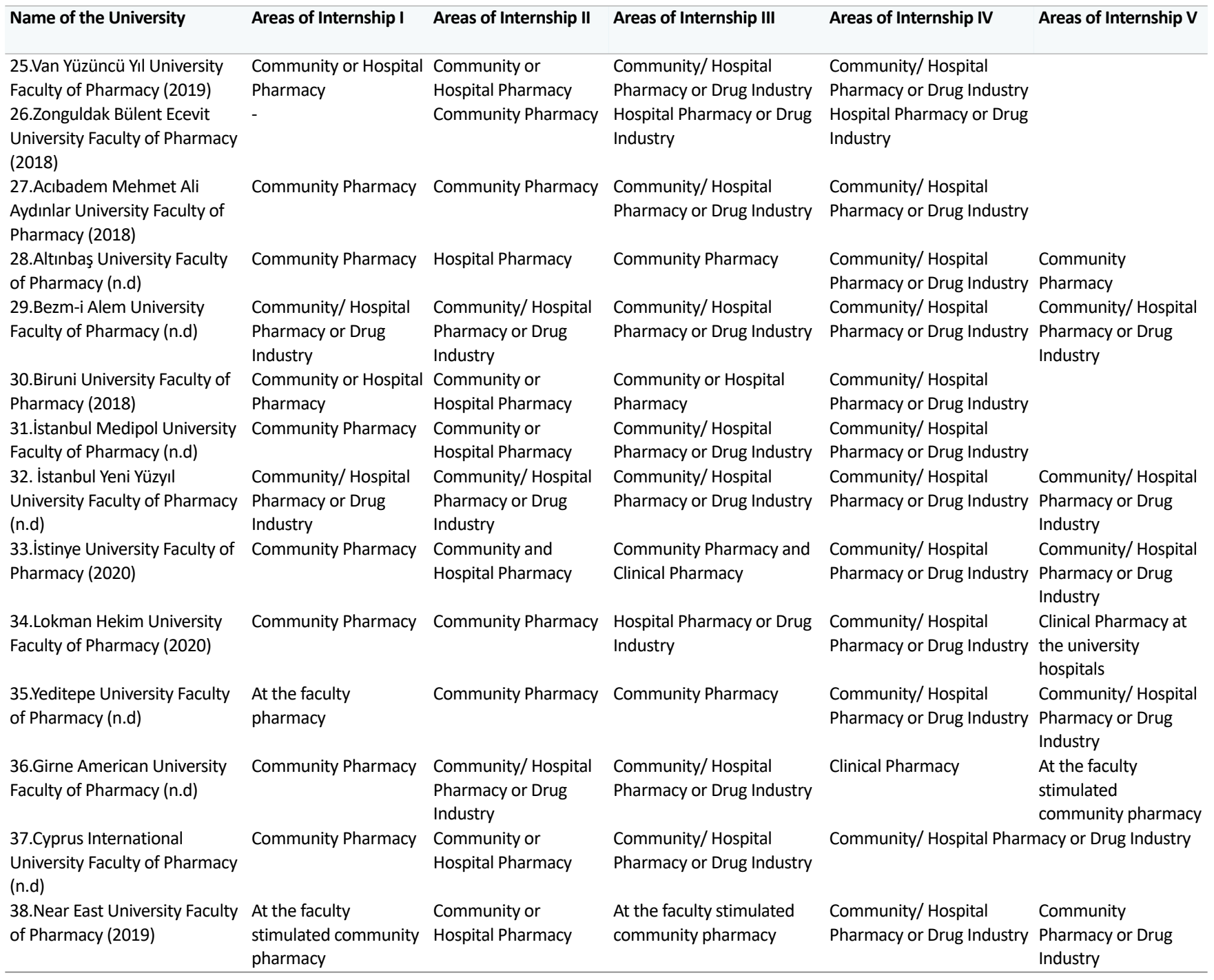

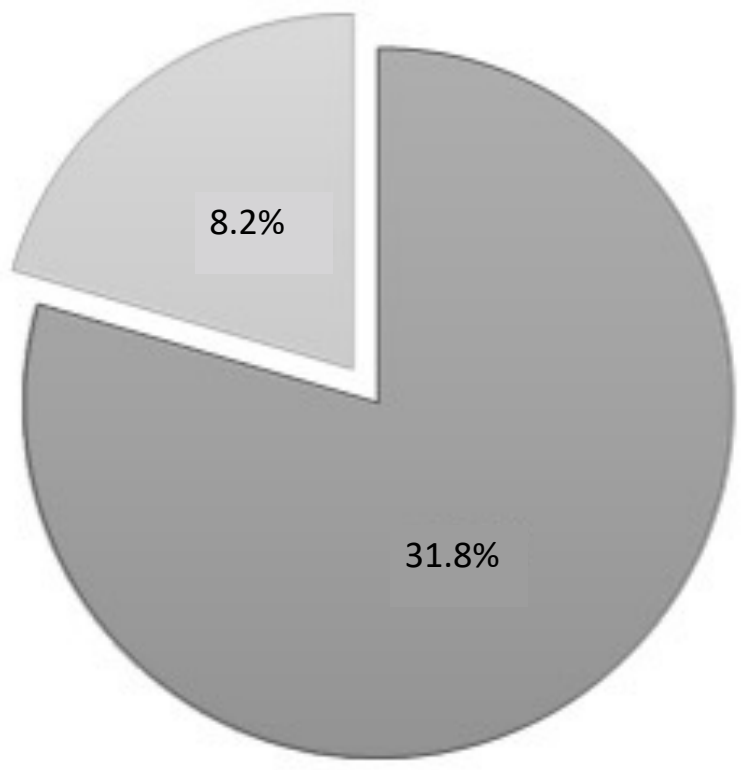

$\square$ Universities that meet the internship standards

$\square$ Universities that do not meet the internship standards

Figure 2: Compliance with the Internship standards $(n=39)$ 
12 month period after the four to five years of professional study at the university. According to the current EU directive on the recognition of professional qualifications concerning pharmacy education (Pitkä et al., 2014), training should include a six month internship in a pharmacy, either in the public setting or in a hospital under the supervision of that hospital's pharmaceutical department. In Finland, the internship is integrated into professional study during the second and third years. An essential part of the Bachelor of Science curriculum in Finland is an obligatory six month internship (30 ECTS credits), which is integrated with professional study at the university. The internship can be taken in a community pharmacy open to the public (minimum three months), or a hospital under the supervision of that hospital's pharmaceutical department (maximum three months) (Pitkä et al., 2014).

The pharmacist undergraduate education in Sweden is a five year programme. In Sweden, Uppsala University and the University of Gothenburg educate pharmacists. Approximately 90 students are accepted twice a year in Uppsala and 90 students a year in Gothenburg. The universities provide equivalent educations, and both universities end their pharmacy programme with a six month pharmacy internship. The students have had no prior internship within the pharmacy programme. Uppsala University offers the internship course twice a year, and the University of Gothenburg once, during the spring term. The internship period is six calendar months, including five days of vacation and two weeks of lectures at the university. Students are employed by the pharmacy during the internship period and receive a monthly salary from the state-owned pharmacy chain. Students are offered opportunities to several study visits at other pharmacies and pharmacy-related workplaces during the internship. It is mandatory to visit at least a hospital pharmacy and a different-sized pharmacy, but students can also arrange study visits on their own. Seminars are often arranged to support the learning of self-medication counselling and over-thecounter (OTC) drugs. An internship is evaluated in several ways. Several assignments are provided by the university to the students to support their learning and the implementation of theory into practice. The assignments included are all mandatory and consist of two reflective essays about communication, oral and written presentations, and pharmacotherapy cases. After passing the prescription dispensing test at halftime, students can gain a temporary legal dispensing right if the tutor and the manager at the pharmacy agree. This allows the student to participate in work on the same premises as a registered pharmacist. The test is mandatory, performed at the pharmacy, and assessed by the tutor. Assessment of the OTC course is done by a written test at the pharmacy, and the tutors are responsible for assessing and discussing the result with students (Wallman, 2010).

Similarly, Pharmacy undergraduate programmes in Brazil have a median duration of ten terms, requiring from students a median of six internships, from the sixth term on, totalising 826 hours (Foppa et al., 2020).

Another example where completing an internship is a must to graduate is in Taiwan. There are several requirements in Taiwan for pharmacy graduates before sitting for the National Board Examination, including completing internships for a total period of 640 hours in a hospital pharmacy setting and 200 hours each in community pharmacy and industry settings (KawaguchiSuzuki et al., 2019).

\section{Discussion}

As a result, considering all of these findings, it is seen that among the pharmacy programmes of the four universities evaluated from the TRNC: only Girne American University's pharmacy programme internship practices comply with the standards, and the pharmacy program-mes of the other three universities follow completely autonomous internship practices which do not meet the standards. Therefore, it is not possible to talk about homogeneity between Turkey and TRNC in terms of pharmacy programmes' internship practices.

When Turkey is considered alone, among the 35 pharmacy faculties that are evaluated in the study, 30 faculties carried out internship practices with minor changes by adhering to the standards $(85.7 \%)$. It is important that the total internship duration in any pharmacy programme has not fallen below six months; as a matter of fact, it was found that this period is exceeded in many programmes. However, five pharmacy faculties do not comply with the standards set by the Council of Deans in either the internship period or the duration of these periods. These faculties are qualified as non-standard.

Another important point is that all pharmacy programmes that are evaluated ensure pharmacy internship in all fields specified in the standards as community, hospital pharmacy and pharmaceutical industry. The employment rate pharmacists in the 
pharmaceutical industry is very low in Turkey, internships in the pharmaceutical industry have been rearranged with the suggestion of the Faculty of Pharmacy Deans' Council to attempt to address this. Thus students who are given internship opportunities in the pharmaceutical industry will also gain an insight into working in a different field. In addition, in the Faculties of Pharmacy, apart from the minimum level of under-graduate education, the applications of the minimum level of internship education are extremely important in terms of gaining the minimum qualifications.

\section{Conclusion}

The authors believe that standardisation of all pharmacy faculties will provide quality pharmacy education all across the country. This is an important issue to ensure equal facilities for all students. As the field of pharmacy education continues to expand and case studies from different countries become more common, the authors look forward to seeing pharmacy education become more and more optimised globally.

\section{References}

Acıbadem Mehmet Ali Aydınlar University Faculty of Pharmacy (2018) (online). Available from: https://kms.kaysis.gov.tr/Home/ Goster/143662

Adıyaman University Faculty of Pharmacy (n.d.) Internship (online). Available from: https://eczacilik.adiyaman.edu.tr/tr/staj

Ağrı İbrahim Çeçen University Faculty of Pharmacy (n.d.) Ağri ibrahim çeçen university faculty of pharmacy internship and professional practice principles (online). Available from: https:// www.agri.edu.tr/upload/eczacilikfakultesidetay252/ Yonetmelikler\%20ve\%20Yonergeler/ Staj\%20ve\%20Mesleki\%20Uygulama\%20Esaslar\%C4\%B1.pdf

Altınbaş University Faculty of Pharmacy (n.d.). Altinbaş university faculty of pharmacy internships (online). Available from: https:// altinbas.edu.tr/p/567/stajlar

Anadolu University Pharmacy Faculty (2019). Anadolu university faculty of pharmacy student internship directive (online). Available from: https://www.anadolu.edu.tr/uploads/anadolu/ ckfinder/web/files/eczacilik-staj-yonergesi.pdf

Ankara University Faculty of Pharmacy (2020). Ankara university faculty of pharmacy internship directive (online). Available from: http://www.pharmacy.ankara.edu.tr/wp-content/uploads/sites/ 70/2020/03/2020-21E\%C4\%9Fitim-
OgretimDenlt\%C4\%B1barenSTAJ-

Y\%C3\%96NERGES\%C4\%BO-2020-SON-HAL\%C4\%BO.pdf

Atatürk University Faculty of Pharmacy (n.d.) The rules to pay attention for the students who will do internship in the year 2019 (online). Available from: https://atauni.edu.tr/tr/2019-eczacilikfakultesi-staj-uygulama-esaslari

Bezm-I Alem University Faculty of Pharmacy (n.d.). Bezm-i alem university faculty of pharmacy internship guideline (online). Available from: http://bezmialem.edu.tr/Documents/eczacilikfakultesi-staj-kilavuzu.pdf

Biruni University Faculty of Pharmacy (2018). Biruni university faculty of pharmacy internship practices and basics (online). Available from: https://eczacilik.biruni.edu.tr/wp-content/ uploads/2016/10/Biruni-U\%cc\%88niversitesiEczac\%c4\%b1l\%c4\%b1k-Faku\%cc\%88Itesi-Staj-UygulamaEsaslar\%c4\%b1-May\%c4\%b1s-2018.pdf

Çukurova University Faculty of Pharmacy (n.d.) Çukurova university faculty of pharmacy internship directive (online). Available from: https://eczacilik.cu.edu.tr/cu/ogrenci/yonergeve-yonetmelikler

Dicle University Faculty of Pharmacy (2021). Dicle university faculty of pharmacy internship directive (online). Available from: http://www.dicle.edu.tr/Dosya/2018-10/stajyonergesi_1735.DOC

Eczacılık Programı Bulunan Tüm Üniversiteler. (n.d.) All Universities with Pharmacy Programs (online). Available from: https://yokatlas.yok.gov.tr/lisans-bolum.php?b=10050

Ege University Faculty of Pharmacy (2019). Ege university faculty of pharmacy internship directive (online). Available from: http:// eczacilik.ege.edu.tr/files/eczacilik/icerik/ ECZACILIK_FAKULTESI_STAJ_YONERGESI_2019.pdf

Erciyes University Faculty of Pharmacy (n.d.) Erciyes university faculty of pharmacy internship basics (online). Available from: https://pharmacy.erciyes.edu.tr/mevzuat/Staj-Esaslari/ErciyesUniversitesi-Eczacilik-Fakultesi/4/27

Erzincan Binali Yıldırım University Faculty of Pharmacy (2018). Erzincan binali yildirim university faculty of pharmacy internship practices (online). Available from: https://eczacilik.ebyu.edu.tr/ wp-content/uploads/2018/08/E\%C3\%9C-Staj-Uygulama\%C4\%BOlke-ve-Esaslar\%C4\%B1-2018-Yeni-isimli.pdf

EU Monitor. Directive 2005/36/EC of the European Parliament and of the Council of 7 September 2005 on the recognition of professional qualifications (Text with EEA relevance) (2005). Official Journal of the European Union. Available from: https:// www.eumonitor.eu/9353000/1/j9vvik7m1c3gyxp/vhckn7aqfiyq

Foppa, A.A., Martins, G.A., Nascimento, R.F., Mesquita, A.R., Mendonça, S.A., \& Chemello, C. (2020) Experiential education in the pharmacy undergraduate curricula in Brazil. Pharmacy Practice (Granada), 18(1), 1738 
Gazi University Faculty of Pharmacy (n.d.) Gazi university faculty of pharmacy internship rules (online). Available from: http:// pharmacy.gazi.edu.tr/posts/view/title/eczacilik-fakultesi-stajkurallari-216054

Hacettepe University Faculty of Pharmacy (2015) hacettepe university faculty of pharmacy (online). Available from: http:// www.eczacilik.hacettepe.edu.tr/tr/ hacettepe_universitesi_eczacilik_fakultesi_lisans_-173

Inönü University Faculty of Pharmacy (2017) inönü university faculty of pharmacy internship directive (online). Available from: https://docplayer.biz.tr/46242527-T-c-inonu-universitesieczacilik-fakultesi-staj-yonergesi-bahar-yariyilindan-itibarenuygulanacaktir.html

Istanbul Medipol University Faculty of Pharmacy (n.d.). İstanbul medipol university faculty of pharmacy internship (online). Available from: https://www.medipol.edu.tr/akademik/ fakulteler/eczacilik-fakultesi/ogrenci/staj-ve-uygulama

Istanbul University Faculty of Pharmacy (n.d.) İstanbul university faculty of pharmacy internship practices rules and basics (online). Available from: https://cdn.istanbul.edu.tr/FileHandler2.ashx? $\mathrm{f}=$ i.u.-eczacilik-fak.-staj-uygulama-ilke-ve-esaslari---v1.pdf

Istanbul Yeniyüzyıl University Faculty of Pharmacy (n.d.). Istanbul yeniyüzyil university faculty of pharmacy internship directive (online). https://yeniyuzyil.edu.tr/mevzuat/StajYonergeleri/ Eczac\%C4\%B1|\%C4\%B1k\%20Fak\%C3\%BCltesi\%20Staj\%20Y\%C3\% B6nergesi.pdf

Istinye University Faculty of Pharmacy (2020). Istinye university faculty of pharmacy internship practices (online). Available from: https://www.istinye.edu.tr/sites/istinye.edu.tr/files/docs/ 2020-01/\%C4\%BOstinye\%20\%C3\%9Cniversitesi\%20Staj\%20ve\%2 0\%C4\%B0\%C5\%9Fyerinde\%20Uygulamal\%C4\%B1\%20Ders\%20Y onergesi.pdf

Karadeniz Teknik University Faculty of Pharmacy (n.d.) Karadeniz teknik university faculty of pharmacy (online). Available from: https://www.ktu.edu.tr/dosyalar/eczacilik_3eaeb.pdf

Kawaguchi-Suzuki, M., Law, M.G., Prisco, J., Head, K., Fu, L., Yumoto, T., Kamei, J., Yang, M., Cheng, K.J., \& Hogue, M.D. (2019). Cultural Sensitivity and Global Pharmacy Engagement in Asia: China, Japan, South Korea, and Taiwan. American journal of pharmaceutical education, 83(4), 7214. https://doi.org/10.5688/ ajpe7214

Lokman Hekim University Faculty of Pharmacy (2020). Lokman hekim university faculty of pharmacy internship directive (online). Available from: https://www.lokmanhekim.edu.tr/ fakulteler/eczacilik-fakultesi/staj-yonergesi-2/

Marmara University Faculty of Pharmacy (2018). Marmara university faculty of pharmacy documents (online). Available from: http://dosya.marmara.edu.tr/ecz/belgeler/word/ \%C3\%B6\%C4\%9Frenci/yonerge_26122018.pdf
Mersin University Faculty of Pharmacy (2018). Mersin university faculty of pharmacy instructions internship basics (online). Available from: http://www.mersin.edu.tr/bulut/birim_1746/ Mevzuat/Is_Yeri_Egitimi_ve_Staj_Mevzuati/ Eczaclk_Fakultesi_Staj_Esaslari.pdf

Near East University Faculty of Pharmacy (2019). Near east university faculty of pharmacy guide book of internship practices (online). Available from: http://eczacilik.neu.edu.tr/wp-content/ uploads/sites/80/2019/03/04/A-Guide-Book-of-PharmacyPractices.pdf

Pitkä, K., Löfhjelm, U., Passi, S., \& Airaksinen, M. (2014). Integrating Internships with Professional Study in Pharmacy Education in Finland. American journal of pharmaceutical education, 78(9), 173. https://doi.org/10.5688/ajpe789173

Reyes, R. (2017). 5 Steps for becoming a rock star Pharmacy Intern (online). Available from: https://www.idstewardship.com/ 5-steps-becoming-rock-star-pharmacy-intern/

Sağlık Bilimleri University Faculty of Pharmacy (Hamidiye) (2019). Sağlik bilimleri university faculty of pharmacy internship directive (online). Available from: http://www.sbu.edu.tr/FileFolder/ Dosyalar/f45a5784/2019_4/staj-yonergesi-pdf-b37f5e4d.pdf

Sağlık Bilimleri University Faculty of Pharmacy (Gülhane) (2019). Sağlik bilimleri university faculty of pharmacy internship directive (online). Available from: http://www.sbu.edu.tr/FileFolder/ Dosyalar/d38f2241/2019_2/gefstajyonergesi-35af17d0.pdf

Selçuk University Faculty of Pharmacy (n.d.). Selçuk university faculty of pharmacy internship directive (online). Available from: https://webadmin.selcuk.edu.tr/BirimDosyalar/Dosyalar/ eczacilik/eczacilik_staj_yonergesi.pdf

Sivas Cumhuriyet University Faculty of Pharmacy (n.d.). Sivas cumhuriyet university faculty of pharmacy internship directive (online). Available from: http://eczacilik.cumhuriyet.edu.tr/ userfiles/file/ECZACILIK/SC\%C3\%9CEF_Staj_Y\%C3\%B6nergesi.pdf

Süleyman Demirel University Faculty of Pharmacy (2020). Süleyman demirel university faculty of pharmacy internship directive (online). Available from: https://eczacilik.sdu.edu.tr/ assets/uploads/sites/283/files/sdu-eczacilik-fakultesi-stajyonergesi-18092020.pdf

TRAKYA University Faculty of Pharmacy (n.d.). Trakya university files (online). Available from: https://bys.trakya.edu.tr/file/open/ 34065859

Özçelikay, G. (2019) mezuniyet öncesi eczacilik eğitimi: Ulusal Eczacılık Çekirdek Eğitim Programı Eczçep-2019 (online). Eczdekankonsey.org. Available from : https:// eczdekankonsey.org/wp-content/uploads/2020/05/ ECZA\%CC\%83-EP-2019.pdf

Van Yüzüncü YIl University Faculty of Pharmacy (2019). Van yüzüncü yil university internship directive change (online). Available from: https://www.yyu.edu.tr/images/files/1Staj_Yonergesi_Degisikligi(1).pdf 
Vestergaard, S., Nørgaard, L.S., Traulsen, J.M., Kaae, S. (2017).

Pharmacy interns' perception of their professional role.

American Journal of Pharmacy Education. 81(1), 10

Wallman, A. (2010). Pharmacy Internship: Students' Learning in a Professional. Practise Setting. PhD Thesis: Acta Universitatis

Upsaliensis

Yeditepe University Faculty of Pharmacy (n.d.). Yeditepe university faculty of pharmacy internships (online). Available from: https://eczacilik.yeditepe.edu.tr/tr/stajlar

Zonguldak Bülent Ecevit University Faculty of Pharmacy (2018). Zonguldak bülent ecevit university faculty of pharmacy internship directive (online). Available from: https://cdn2.beun.edu.tr/ eczacilik//2018/07/1/staj-yonetmeligi04072018.pdf 